\title{
PENEGAKAN HUKUM PERLINDUNGAN KONSUMEN SEBAGAI UPAYA PENINGKATAN MUTU PRODUKSI NASIONAL
}

\author{
Ali Mansyur, Irsan Rahman \\ Dosen Fakultas Hukum UNISSULA \\ M_alimansur@yahoo.co.id
}

\begin{abstract}
As the Consumer Protection Law Enforcement Effort for Quality Improvement National Production outlines that globalization opens free market requires businesses to compete on a competitive basis from the galloping pace of international business competition. Opportunities entry of goods imported from abroad should be able to be supported by regulations to safeguard the rights of consumers and businesses nationwide are required to produce a quality prodak capable of fulfilling the rights of consumers and be able to compete competitively in the global market. The research method using normative juridical approach with The data collection methods focus on literature study materials secondary law. research shows that the production quality standardization aims to improve consumer protection and to realize smooth trade and a healthy business climate, embody the fulfillment of the rights of consumers, and improve the quality of prodak grade; The next responsibility of businesses in ensuring the quality of the production is to provide the fulfillment of the rights of consumers, the conception of the activities prohibited to businesses in the form of regulations to not produce harmful products and are not qualified, and quality standardization efforts of national production; whereas consumer protection law enforcement efforts in improving the quality of national production is through the efforts of standardizing the quality of production, the preventive consumer protection and dispute settlement, prosecution and sanctioning both on aspects of criminal, civil and administrative.
\end{abstract}

Keywords: Law Enforcement, Consumer Protection, Quality Improvement Production

\begin{abstract}
Abstrak
Penegakan Hukum Perlindungan Konsumen Sebagai Upaya Peningkatan Mutu Produksi Nasional menguraikan bahwa globalisasi membuka pasar bebas yang menuntut pelaku usaha bersaing secara kompetitif dari derap langkahnya persaingan dunia usaha internasional. Peluang masuknya barang impor dari luar negeri harus mampu didukung oleh regulasi yang dapat menjaga hakhak konsumen dan pelaku usaha nasional dituntut untuk memproduksi prodak yang berkualitas yang mampu memenuhi hak-hak konsumen sekaligus mampu bersaing secara kompetitif di pasar global. Metode penelitian menggunakan Pendekatan Yuridis Normatif dengan Metode Pengumpulan Datanya fokus pada Studi Kepustakaan bahan-bahan hukum sekunder. hasil penelitian menunjukan bahwa standardisasi mutu produksi bertujuan untuk meningkatkan perlindungan konsumen serta mewujudkan kelancaran perdagangan dan iklim usaha yang sehat, mewujudkan pemenuhan hakhak konsumen, dan meningkatkan kualitas prodak yang bermutu; selanjutnya tanggung jawab pelaku usaha dalam menjamin mutu produksi adalah memberikan pemenuhan hak-hak konsumen, konsepsi dari kegiatan yang dilarang kepada pelaku usaha dalam bentuk regulasi untuk tidak memproduksi produk yang berbahaya dan tidak bermutu, dan upaya standardisasi mutu produksi nasional; sedangkan upaya penegakan hukum perlindungan konsumen dalam meningkatkan mutu produksi nasional adalah melalui upaya standardisasi mutu produksi, upaya preventif perlindungan konsumen serta penyelesaian sengketa, penuntutan dan pemberian sanksi baik pada aspek pidana, perdata dan admininstratif.
\end{abstract}

Kata kunci: Penegakan Hukum, Perlindungan Konsumen Peningkatan Mutu Produksi.

\section{A. PENDAhUluAN}


Saat globalisasi ekonomi terjadi, batas-batas wilayah suatu negara akan semakin kabur sehingga menimbulkan ketertarikan antar ekonomi nasional dengan ekonomi internasional. Globalisasi ekonomi memiliki pengaruh yang positif dan negatif. Pengaruh positif globalisasi dalam bidang ekonomi akan memberikan peluang produk negeri ke pasar internasional secara kompetitif, sedangkan pengaruh negatif globalisasi ekonomi adalah membuka peluang masuknya produk luar negeri ke dalam pasar nasional.

Globalisasi sebagai akibat pesatnya kemajuan di bidang transportasi dan komunikasi ternyata menimbulkan semakin besarnya ketergantungan antar bangsa, kemudian juga timbulnya tingkat kompentensi yang semakin tajam. Persaingan yang semakin keras membawa tuntutan pada kualitas produk dan tingkat efisiensi yang semakin tinggi. Dalam pandangan dunia bisnis, globalisasi tidak hanya sekedar berdagang di beberapa negara di dunia, tetapi berdagang di seluruh dunia dengan cara baru, yang menjaga keseimbangan antara kualitas produksi dengan kebutuhan khas yang bersifat lokal dari konsumen, cara baru ini dipengaruhi oleh saling ketergantungan antar bangsa yang saling meningkat, berlakunya standarstandar dan kualitas baku internasioanal, melemahnya ikatan-ikatan etnosentrik yang sempit, peningkatan peran swasta dalam bentuk korporasi internasioanal, melemahnya ikatan-ikatan nasional dibidang ekonomi dan peranan informasi sebagai kekuatan baru. ${ }^{1}$

Sebagai contoh di Indonesia, produk elektronik asal China saat ini mulai mendapatkan kepercayaan masyarakat. Hal ini karena produk-produk asal China sudah mulai menunjukan kualitasnya dan mampu bersaing dengan beberapa merk dagang yang lain. Seiring dengan meningkatnya kepercayaan masyarakat terhadap produk asal China, Midea Electronics sebagai salah satu produk keluaran China, yakin hingga akhir 2013 ini mampu terus meningkatkan jumlah penjualannya. Untuk produk Midea sendiri,

1 Daniel, dalam Muladi, 2010, Aspek Hukum Globalisasi, penerbit: UNDIP, Semarang, tanpa halaman pihaknya memprediksi penjualan elektronik hingga akhir tahun ini bisa tumbuh sebesar 18 persen, bahkan pada 2014 pihaknya tetap optimis mampu tumbuh hingga 22 persen. ${ }^{2}$

Bukan hanya China, Indonesia yang masih belum tergolong negara maju, tidak kalah tertinggal. Banyak produk ternama di dunia mempercayakan Indonesia untuk memproduksi sebagian bahkan seluruh produk mereka. Hal ini tentu saja membanggakan, terutama di saat banyak orang Indonesia menginginkan serta mempercayai produk luar negeri yang di anggap lebih baik, ternyata orang luar negeri mempercayai produk Indonesia sebagai buatan yang terbaik dan mereka memilih negara kita untuk memproduksi barang dan benda yang namanya sudah mendunia. Dan berikut 7 (tujuh) produk Indonesia yang mendunia, adalah sebagai berikut: ${ }^{3}$

1. Seragam NATO;

2. Boneka barbie;

3. Airbridge bandara;

4. Knalpot mercedes benz;

5. Radio magno;

6. Alat pembasmi kanker otak;

7. Sepeda polygon.

Manajemen dunia usaha dalam menghadapi kompetensi global bukan merupakan hal yang dianggap enteng, justru menuntut pihak-pihak yang terlibat mencurahkan kinerja yang baik dan solid, jika kondisi ini tidak terwujud, maka pengusaha kita akan tertinggal oleh derap langkahnya pengusaha ditingkat nasioanal maupun internasional. Dunia usaha sebagai penggerak utama ekonomi yang handal dan sehat, perlu di kembangkan "competitive advantage" disamping itu harus didukung oleh pemerintahan yang baik. ${ }^{4}$ Pemerintah baik yang dimaksud adalah pemerintahan

2 Andik Sismanto, Produk Elektronik China Mulai Dipercaya Pasar Indonesia, www.ekbis.sindonews. com diunduh pada tanggal 16 Desember 2013 pukul 19:23 WIB

3 zulkifli, 7 Buatan Indonsia Yang Mendunia, www. zulkifli19.wordpress.com diunduh pada tanggal 23 december 2013 pukul 19.00 WIB

4 Sri adiningsih, 1998, Pemberdaulatan Ekonomi Rakyat Untuk Meningkatkan Kesejahteraan Masyarakat, Kertas Karya pada seminar FE Unissula, Semarang, hlm. 3 
yang telah melaksanakan prinsip-prinsip "good governance" serta didukung pula oleh lembaga dan pranata hukum yang baik serta peraturan perundang-undangan yang baik pula.

Indonesia sebagai negara hukum kesejahteraan senantiasa mempunyai citacita luhur sebagaimana di kemukakan dalam pembukaan UUD 1945 diatas. Salah satu bentuk langkah kongkrit dalam melaksanakan cita-cita luhur yang menjadi amanah negara adalah melindungi segenap atau seluruh warga negaranya dari perbuatan tidak baik yang bisa saja merugikan rakyatnya. Hukum perlindungan konsumen merupakan upaya hukum untuk melindungi konsumen (warga negara) dari perbuatan curang oknum pelaku usaha baik dari dalam negeri maupun dari luar negeri. Oleh karena itu, hukum perlindungan konsumen merupakan upaya kongkrit yang dilakukan oleh negara dan pemerintah untuk melindungi konsumen (warga negara) sebagaimana amanah dari konsepsi negara hukum kesejahteraan yang termuat dalam amanah konstitusi UUD 1945.

Salah satu konsideran UndangUndang Nomor 8 Tahun 1999, isu perlindungan konsumen merupakan suatu hal yang ada keterkaitan ekspansi dunia usaha yang menglobal. Semakin terbukanya pasar nasional sebagai akibat globalisasi ekonomi harus tetap menjamin peningkatan kesejahteraan masyarakat serta kepastian atas mutu, jumlah, dan keamanan barang dan atau jasa yang diperoleh di pasar. Untuk meningkatkan harkat dan martabat konsumen perlu meningkatkan kesadaran, pengetahuan, kepedulian, kemampuan, dan kemandirian konsumen untuk melindungi dirinya serta menumbuhkembangkan sikap pelaku usaha yang bertanggung jawab. ${ }^{5}$

Undang-Undang Perlindungan Konsumen (UUPK) masih belum menunjukan adanya keberpihakan dan terakomodasinya keluhan-keluhan konsumen. Lemahnya pelaksanaan Undang-Undang Pelindungan

5 Ade Maman Suherman, 2005, Aspek Hukum Dalam Ekonomi Global, Cet.ke 2 (Edisi Revisi), Ghalia Indonesia, Bogor, hlm.97
Konsumen ternyata telah dimanfaatkan oleh para pelaku bisnis global dan pelaku usaha nasional untuk menjual produksinya yang unsafe dan understandard. Kondisi ini semakin diperburuk dengan lemahnya dan tidak memadainya pendidikan konsumen terhadap akibat buruk dari penggunaan barangbarang yang tidak aman dan dibawah standar. Oleh, karena itu semua pihak menginginkan penegakan hukum perlindungan konsumen yang sebaik-baiknya. ${ }^{6}$

Semestinya korporasi harus mewujudkan perlindungan konsumen sebagai strategi untuk menarik simpati konsumen termasuk agar produk yang di hasilkan dapat diterima oleh konsumen. Apa yang terjadi selama ini di Indonesia justru bertolak belakang dari idealisme tersebut, setiap kali kita menyaksikan tindakan-tindakan korporasi yang melanggar hukum dan merugikan rakyat banyak korporasi (pengusaha) hampir selalu tidak tersentuh oleh hukum, banyak kasus yang telah terjadi seperti kasus biskuit beracun, kasus ajinomoto, kasus keracunan obat, dan lain-lain, yang jelas-jelas telah mencuat kepermukaan, namun terkesan birokrasi pemerintah membiarkan dalam arti tidak mengambil tindakan terhadap korporasi yang merugikan masyarakat, bahkan membantah, tidak mengklarifikasi, menutupi, kurang bukti atau seakan-akan mengambil tindak namun tidak ada kelanjutannya. ${ }^{7}$

Manfaat dari aspek penegakan hukum perlindungan konsumen adalah untuk memberikan kenyamanan terhadap masyarakat (konsumen), karena dengan dilaksanakannya penegakan hukum perlindungan konsumen maka dampak hukum bagi korporasi (pelaku usaha) sebagai produsen akan berhati-hati akan resiko hukum, secara tidak langsung korporasi-korporasi akan berusaha untuk meningkatkan kualitas mutu produksinya. Tingkah laku orang di masyarakat akan 6 Ibid.,

7 M. Ali Mansyur, 2012, Peran Hukum Dalam Menjawab Perkembangan Ekonomi, Makalah Disampaikan Pada Kuliah Peranan Hukum Dalam PembangunanEkonomi, Bagian Hukum Perdata Fakultas Hukum Universitas Islam Sultan Agung, Semarang, hlm.1 
berorientasi kepada berbagai hal dan patokan. Sulit diterima bahwa tingkah laku orang dalam masyarakat itu bebas, melainkan sebaliknya didisiplinkan oleh pembatasanpembatasan. Oleh Parsons dikatakan bahwa tingkah laku seperti tersebut tunduk kepada suatu skema tertentu yang disebut sebagai relational scheeme. ${ }^{8}$ Oleh karena itu, salah satu upaya untuk meningkatkan mutu produksi nasional adalah dengan memberlakukan standardisasi nasional, memberikan tanggung jawab kepada pelaku usaha (produsen) untuk senantiasa menjaga mutu produksinya, dan menegakan hukum perlindungan konsumen dalam meningkatkan mutu produksi nasional. Penegakan hukum perlindugan konsumen harus dipahami secara holistik dan komprehensif mulai dari upaya hukum preventif seperti penyuluhan kepada masyarakat sampai kepada pemberlakuan standardisasi nasional terhadap mutu produksi dan penegakan hukum represif di muka peradilan dan pemberian sanksi-sanksi kepada pelaku usaha yang melanggar hukum.

Berdasarkan uraian yang dikemukakan diatas, maka dapat dirumuskan beberapa masalah dalam usulan penelitian ini, adalah sebagai berikut:

1. Bagaimana standardisasi mutu produksi nasional dilihat dari aspek hukum perlindungan konsumen?

2. Bagaimana tanggung jawab pelaku usaha (produsen) dalam hukum perlindungan konsumen dilihat dari jaminan mutu produksi?

3. Bagaimana penegakan hukum perlindungan konsumen dalam meningkatkan mutu produksi nasional?

\section{B. METODE PENELITIAN}

Metode penelitian yang dipakai dalam penelitian ini menggunakan metode Penelitian hukum normatif yang mendasarkan hukum sebagai norma dengan metodenya bersifat doktrinal. Sedangkan penelitian hukum empiris memiliki maksud untuk mempelajari saja dan bukan mengajarkan suatu doktrin, sehingga

8 Talcot Parsons, 1951, The Social System, The Free Press, New York, hlm.4 metodenya bersifat non-doktrinal.

Dalam penelitian hukum normatif, penelitian dilakukan dengan cara meneliti bahan pustaka atau data sekunder saja, sedangkan dalam penelitian hukum sosiologis penelitian dilakukan dengan meneliti data primer yang diperoleh langsung dari masyarakat (data dasar). ${ }^{9}$

\section{HASIL PENELITIAN DAN PEMBAHASAN}

1. Bagaimana standardisasi mutu produksi nasional dilihat dari aspek hukum perlindungan konsumen

Hukum merupakan suatu sistem yang penting dalam pelaksanaan rangkaian kewenangan dan kekuasaan kelembagaan Negara dan Pemerintah dalam aspek yang sempit. ${ }^{10}$ Dari bentuk penyalahgunaan kekuasaan dalam bidang politik, ekonomi, dan sosial-masyarakat dalam berbagai cara dan bertindak, hukum berperan sebagai instrumen penting dalam menciptakan suatu kondisi yang stabil dalam penyelenggaraan Negara. Hukum menjadi batasan bagi Pemerintah dalam bersikap tindak dalam melakukan suatu perbuatan hukum sehingga tetap taat asas dan dapat menyediakan kerangka kerja bagi dalam penciptaan hukum, perlindungan hak asasi manusia.

Sebagaimana telah dijelaskan diatas bahwa standardisasi adalah bertujuan untuk meningkatkan perlindungan hukum terhadap konsumen. Upaya standardisasi mutu barang diharapkan kepada pelaku usaha untuk mampu mewujudkan kelancaran perdagangannya dan mewujudkan iklim

9 Ronny Hanitijo Soemitro, 1983, Metodologi Penelitian Hukum dan Jurimetri, Ghalia Indonesia, Jakarta, hlm.97.

10 Robertson, Crimes Against Humanity, 90; see "analytical jurisprudence" for extensive debate on what law is; in The Concept of Law Hart argued law is a "system of rules" (Campbell, The Contribution of Legal Studies, 184); Austin said law was "the command of a sovereign, backed by the threat of a sanction" (Bix, John Austin); Dworkin describes law as an "interpretive concept" to achieve justice (Dworkin, Law's Empire, 410); and Raz argues law is an "authority" to mediate people's interests (Raz, The Authority of Law, 3-36). 
usaha yang sehat.

Upaya hukum preventif dalam perlindungan konsumen yaitu pembinaan dan kebijakan peningkatan mutu dengan memberlakukan standardisasi mutu produksi. Standardisasi mutu produksi bertujuan untuk mewujudkan hak-hak konsumen sebagaimana ketentuan dalam Pasal 4 Undang-Undang Perlindungan Konsumen (UUPK). Manfaat dari standardisasi mutu produksi nasional pada upaya penegakan hukum represif pada perlindungan konsumen adalah menjadi acuan standar bagi aparat penegakan hukum dalam mengevaluasi mutu produk.

Kesadaran pelaku usaha dalam standardisasi mutu produksi senantiasa ditaati oleh pelaku usaha sebagaimana ketentuan hukum yang berlaku sangat diharapkan karena standardisasi mutu adalah acuan atau pedoman bagi para pelaku usaha untuk menjaga sifat mutu produksi yang unsafe dan understandard, sebagaimana diketahui bahwa barang yang unsafe dan understandard dapat membahayakan masyarakat (konsumen)

Standardisasi pada hakikatnya merupakan larangan dan kewajiban kepada pelaku usaha, konsep larangan dalam standardisasi mutu produksi adalah larangan memproduksi suatu prodak dengan kualitas yang tidak baik atau dibawah standar dan konsep kewajiban adalah kewajiban bagi pelaku usaha untuk memproduksi suatu prodak dengan kualitas yang baik.

Kebijakan standardisasi seharusnya membawa paradigma kepada para pelaku usaha (produsen) akan kepastian batas mutu atau kualitas yang ditentukan dan diterima pasar sehingga konsumen memperoleh kepastian kualitas dan keamanan produk, sehingga publik dilindungi dari segi keamanan, kesehatan, keselamatan, dan kelestarian lingkungannya.

Standardisasi mutu produksi sebagai standar etika dalam perlindungan konsumen menimbulkan pertanyaannya, seberapa efektifkah sosialisasi dan pendidikan etika kepada para pelaku usaha sedangkan pelaku usaha dalam dunia usaha adalah mencari keuntungan; pada persoalan perlindungan konsumen sangat susah jika hanya mengharapkan nurani dari pelaku usaha. Pesan-pesan moral dalam etika bisnis seperti kejujuran, keadilan, itikad baik harus diaktualisasikan dalam sebuah kebijakan yang harus diindahkan.

Standar meningkatkan keunggulan kompetitif dan kualitas kehidupan bangsa, standar menjadi alat yang berdaya guna untuk mengarahkan perubahan positif dengan spesifikasi terperinci untuk membuka pasar global, menciptakan lingkungan yang dapat mendukung bisnis, memacu pertumbuhan ekonomi. Daya dukung standar produksi dari pasar global dan pertumbuhan ekonomi tidak lain dipengaruhi oleh prilaku konsumen yang menginginkan produk yang tidak berbahaya yaitu produk yang mendukung keamanan, kesehatan, keselamatan, dan kelestarian lingkungan.

Budaya mutu perlu diciptakan baik dikalangan konsumen, masyarakat pada umumnya dan juga dunia usaha sedemikian sehingga kesadaran akan mutu tersebut akan mampu menciptakan perlindungan pasar domestik yang kuat atas inisiatif masyarakat dan dunia usaha. penerapan SNI yang saat ini lebih banyak digerakan oleh pemerintah melalui pemberlakuannya secara wajib didalam regulasi tekhnis berbasis $\mathrm{SNI}$, perlu digerakkan kearah penerapan SNI secara sukarela, dan kesadaran masyarakat untuk memilih produk berstandar SNI, karena keunggulan kompetitif dari produkproduk bertanda SNI.

Dengan standardisasi mutu produksi paham akan kepastian batas mutu atau kualitas yang diterima pasar, sedangkan konsumen memperoleh kepastian kualitas dan keamanan produk, sehingga publik dilindungi dari segi 
keamanan, kesehatan, keselamatan dan kelestarian lingkungannya

\section{Tanggung Jawab Pelaku Usaha Dalam Menjamin Mutu Produksi}

Pada dasarnya ada hubungan antara pelaku usaha dan konsumen, hubungan yang dimaksud adalah hak dan kewajiban antara pelaku usaha dan konsumen, oleh karena itu Hukum perlindungan konsumen mengatur hak dan kewajiban pelaku usaha dan konsumen yang dijamin pemenuhannya melalui penegakan hukum. Kewajiban pelaku usaha merupakan tanggung jawab yang harus di emban oleh pelaku usaha kepada konsumen dan sebaliknya hak konsumen adalah kewajiban konsumen kepada pelaku usaha.

Tanggung jawab pelakusa usaha dalam perlindungan konsumen dapat dikategorikan dalam 3 (tiga) aspek, yaitu:

1. Kegiatan yang dilarang kepada pelaku usaha;

2. Pemenuhan hak-hak konsumen;

3. Standardisasi mutu produksi.

Kegiaatan yang dilarang kepada pelaku usaha secara garis besar adalah larangan terhadap perbuatan yang tidak boleh menciderai kualitas barang sebagaimana diatur dalam Pasal 8 ayat 1 huruf (a) yang meliputi standar yang dipersyaratkan, berat bersih, isi bersih atau netto, ukuran, takaran, timbangan, kondisi, jaminan, keistimewaan atau kemanjuran, proses pengolahan dan lain sebagainya.

Pemenuhan hak-hak konsumen sebagaimana diatur dalam Pasal 4 UUPK adalah hak konsumen mendapatkan produk yang baik sehingga pelaku usaha harus memberikan produk yang berkualitas. Ada hubungan sebab akibat antara aspek kegiatan yang dilarang kepada pelaku usaha dan pemenuhan hak konsumen, jika pelaku usaha telah mampu mengindahkan kegiatan yang dilarang kepada pelaku usaha maka secara otomatis hak-hak konsumen telah terpenuhi; oleh karena itu, kegiatan yang dilarang kepada pelaku usaha dan hakhak konsumen merupakan hubungan sebab akibat dari hak dan kewajiban. Antara kegiatan yang dilarang kepada pelaku usaha dan hak-hak konsumen merupakan aktualisasi konkrit dari hak dan kewajiban pelaku usaha dan konsumen.

Manfaat standardisasi mutu produksi bertujuan untuk menetapkan kualitas mutu yang baik dengan menetapkan atau menentukan kualitas minimum yang harus diproduksi, kualitas minimum tersebut seyognya telah berkualitas namun hanya ditekankan pada aspek apa yang tidak boleh melewati ambang batas yang ditetapkan atau ditentukan pada level dibawah mutu atau kualitas. Oleh karena itu, standardisasi itu semata-mata adalah upaya untuk menjaga kualitas atau mutu produksi sehigga jaminan mutu produksi dapat dirasakan oleh konsumen.

Kegiatan yang dilarang kepada pelaku usaha, pemenuhan hak-hak konsumen dan standardisasi mutu produksi dalam menjamin mutu produksi bukan merupakan pilihan-pilihan yang bersifat parsial atau terpisah namun merupakan satu kesatuan yang integral yang harus dijalankan secara bersamasama karena hal-hal tersebut merupakan sebab akibat dari hak dan kewajiban pelaku usaha.

\section{Penegakan Hukum Perlindungan Konsumen Dalam Rangka Meningkatkan Mutu Produksi Nasional Pelaku ekonomi diharuskan} meningkatkan kemampuannya untuk bersaing, baik dalam memproduksi serta memasarkan suatu produk maupun untuk melakukan penerobosan pasar yang batas-batasnya semakin luas, atau dengan kata lain harus mampu bersaing dalam atmosfer perekonomian yang sangat kompetitif. Hal ini disebabkan pada era ini kemampuan produksi dan pemasaran harus dilandaskan pada 
kemampuan menciptakan barang yang laku di pasar global dengan memanfaatkan perkembangan teknologi, sekaligus adanya perhatian untuk mencermati isu-isu strategis yang berkembang.

Salah satu hal penting yang harus dicermati dengan adanya perekonomian kompetitiftadi adalah dampak perdagangan bebas dengan pasar yang semakin terbuka yang membuat tidak adanya pagar-pagar pembatas atas produk global untuk masuk ke Indonesia. Arus impor dimulai dari bahan baku, barang modal, hingga barang konsumsi akan membanjiri dalam negeri. Di satu sisi, hal keterbukaan ini akan meningkatkan skala ekonomi, yang berarti keuntungan bagi produsen, serta semakin luasnya pilihan barang yang tersedia yang menjadi keuntungan bagi konsumen. Namun di sisi lain, untuk saat ini harus meningkatkan regulasi dengan menggunakan instrumen non-tarif, antara lain dengan memberlakukan peraturan teknis penggunaan standar produk dan penilaian kesesuaian untuk menjaga kepentingan domestik dari masuknya barang impor.

Sebagai sikap yang sekaligus menjadi jawaban atas fenomena perekonomian, khususnya perdagangan yang berkembang pesat dan kompetitif sangat dibutuhkan peran pengembangan mutu barang menjadi penting dalam kerangka upaya Indonesia untuk selalu meningkatkan kualitas mutu produksi agar mampu bersaing dalam liberalisasi perdagangan internasional, sekaligus untuk mengamankan kepentingan konsumen di tanah air.

Bentuk pelayanan yang diselenggarakan bagi publik guna mendorong serta mengembangkan mutu barang adalah pelayanan pelaksanaan kebijakan pemantauan ketertelusuran mutu barang, pelayanan bimbingan teknis dan pembinaan di bidang mutu barang, pelayanan terhadap SDM pengujian mutu barang, pelayanan pengujian, dan sertifikasi di bidang mutu barang.
Pembangunan perdagangan jangka panjang menekankan pada 2 (dua) komponen penting yaitu di bidang perdagangan luar negeri dan perdagangan dalam negeri. Di bidang perdagangan luar negeri, proses maupun kebijakan perdagangan harus lebih mendatangkan keuntungkan dan mendukung perekonomian nasional agar mampu memaksimalkan manfaat sekaligus meminimalkan efek negatif dari proses integrasi dengan dinamika globalisasi.

Perdagangan dalam negeri harus ada proses dan kebijakan perdagangan diarahkan untuk memperkokoh sistem distribusi nasional yang efisien dan efektif yang menjamin kepastian berusaha dalam kerangka mewujudkan berkembangnya lembaga perdagangan yang efektif dalam perlindungan konsumen dan persaingan usaha secara sehat, terintegrasinya aktivitas perekonomian nasional dan terbangunnya kesadaran penggunaan produksi dalam negeri, meningkatnya perdagangan antar wilayah/daerah, serta terjaminnya ketersediaan bahan pokok dan barang strategis lainnya dengan harga yang terjangkau.

Pasar bebas menuntut kalangan industri memiliki daya saing agar dapat memenangkan persaingan di pasar domestik, regional dan global. Daya saing industri sangat ditentukan oleh kualitas sumberdaya manusia (SDM). Ketersediaan SDM berkualitas berakar dan mengalir dari kualitas lembaga dan sistem penegakan hukum dalam mempersiapkan dan mengawal kegiatan ekonomi untuk mendorong iklim usaha yang kompetitif.

Aspek-aspek yang berkaitan dengan pelaksanaan penegakan hukum perlindungan konsumen meliputi aspek pengamanan pasar dalam negeri, standardisasi mutu, pengembangan mutu barang, pengawasan barang dan jasa yang beredar, hingga pada penanganan kasus dan pengaduan konsumen. 
Pelaksanaan pengawasan barang beredar dan jasa, diharapkan dapat membendung kemungkinan masuknya barang-barang yang tidak sesuai dengan ketentuan atau peraturan yang berlaku. Dalam kerangka melindungi konsumen, pengembangan fungsi perlindungan konsumen diarahkan untuk membangun konsumen yang cerdas, yaitu konsumen yang mengetahui serta memahami hak dan kewajibannya.

Penegakan hukum perlindungan konsumen senantiasa mendorong pelaku usaha untuk meningkatkan daya saing dengan menghasilkan produk bermutu sesuai ketentuan atau peraturan yang berlaku dan menciptakan iklim perdagangan dalam negeri yang sehat dan kondusif.

Upaya penegakan dalam perlindungan konsumen bukan saja pada penyelesain sengketa konsumen untuk memberikan hak dan kewajiban konsumen dalam perkara sengketa konsumen, tetapi harus dimulai dari upaya pengawasan dan standardisasi mutu produksi. standardisasi mutu produksi menekan pada apa yang harus di produksi oleh produsen dan menjamin kualitas dari produksi-produksi para produsen atau pelaku usaha.

Upaya penegakan hukum dalam penyelesaian sengketa konsumen dan pemberian sanksi bertujuan memberikan kesadaran dan kehati-hatian bagi pelaku usaha. Oleh karena itu penegakan hukum pada penerapan sanksi atau hukuman baik pada aspek pidana, perdata, dan aspek admininstratif semata-mata hanya untuk merangsang sikap pelaku usaha ataupun juga terhadap konsumen itu sendiri terkait manajemen resiko, manajemen resiko yang dimaksud adalah manajemen resiko hukum.

\section{PENUTUP}

\section{Kesimpulan}

Berdasarkan hasil penelitian yang telah dilakukan, penulis menarik kesimpulan bahwa:
1. Standardisasi mutu produksi bertujuan untuk meningkatkan perlindungan konsumen dan pelaku usaha, mewujudkan kelancaran perdagangan dan mewujudkan iklim usaha yang sehat. Standardisasi mutu produksi juga bertujuan untuk mewujudkan hak-hak konsumen sebagaimana ketentuan dalam Pasal 4 Undang-Undang Perlindungan Konsumen (UUPK). Manfaat dari standardisasi mutu produksi nasional adalah memberikan kualitas barang yang bermutu sehingga konsumen dapat terpenuhi haknya dan pada upaya penegakan hukum represif adalah menjadi acuan standar bagi aparat penegakan hukum dalam mengevaluasi mutu produk.

2. Tanggung jawab pelaku usaha dalam perlindungan konsumen untuk menjamin mutu produksi adalah larangan-larangan kepada pelaku usaha dalam memproduksi suatu produk, pemenuhan hak-hak konsumen, manfaat standardisasi mutu produksi. Larangan bagi pelaku usaha secara garis besar adalah larangan terhadap perbuatan yang tidak boleh menciderai kualitas barang atau standar sebagaimana diatur dalam Pasal 8 ayat 1 huruf (a), pemenuhan hak-hak konsumen sebagaimana diatur dalam Pasal 4 UUPK adalah hak konsumen mendapatkan produk yang baik sehingga pelaku usaha harus memberikan produk yang berkualitas. Standardisasi produksi bertujuan untuk menetapkan kualitas minimum yang harus diproduksi, kualitas minimum tersebut seyognya telah berkualitas namun hanya ditekankan pada aspek apa yang 
tidak boleh diproduksi melewati ambang batas yang ditentukan. Oleh karena itu, standardisasi itu semata-mata adalah upaya untuk menjaga kualitas atau mutu produksi sehigga jaminan mutu produksi dapat dirasakan oleh konsumen. Jaminan mutu adalah hal pokok dalam perlindungan konsumen, boleh dikata jika jaminan mutu telah terwujud, maka perlindugan konsumen ditiadakan saja.

3. Upaya penegakan dalam perlindungan konsumen bukan saja pada penyelesain sengketa konsumen untuk memberikan hak dan kewajiban konsumen dalam perkara sengketa konsumen, tetapi harus dimulai dari upaya pengawasan dan standardisasi mutu produksi. standardisasi mutu produksi menekan pada apa yang harus di produksi oleh produsen dan menjamin kualitas dari produksi-produksi para pelaku usaha. Upaya penegakan hukum dalam penyelesaian sengketa konsumen dan pemberian sanksi memberikan kesadaran dan kehati-hatian bagi pelaku usaha. Oleh karena itu penegakan hukum pada pemberian sanksi atau hukum baik pada aspek pidana, perdata, dan aspek admininstratif semata-mata hanya untuk merangsang sikap pelaku usaha terkait manajemen resiko, manajemen resiko yang dimaksud adalah manajemen resiko hukum.

\section{Saran}

1. Lembaga-lembaga standardisasi nasional seperti Direktorat Standardisasi Kementrian Perdagangan, Kementrian Perindustrian, Badan Standardisasi Nasional (BSN), dan Badan Pengawas Obat dan Makanan (BPOM) untuk lebih meningkatkan upaya pengembangan standardisasi nasional melalui upaya strategi seperti pelayanan yang memadai yang mampu dijangkau oleh pelaku usaha dengan mudah seperti pelayanan pendaftaran melalui on-line (internet) dan biaya pendaftaran yang murah sehingga tidak membebani pelaku usaha dalam mendaftarkan atau mendapatkan SNI. Kepada pelaku usaha (produsen) agar senantiasa berusaha memproduksi barang dengan kualitas yang baik sebagaimana yang telah ditentukan dalam standardisasi mutu produk dan menjamin kualitas prodak yang baik untuk memenuhi hak-hak konsumen dan prodaknya lebih berkompetitif sehingga dapat menembus pasar global.

2. Kepada pelaku usaha untuk senantiasa menjaga atau menjamin kualitas mutu produksinya yaitu dengan upaya-upaya untuk memenuhi hak-hak konsumen, mengindahkan larangan-larangan perbuatan bagi pelaku usaha dan berusaha untuk mendaftarkan dan mendapatkan SNI.

3. Aparat penegak hukum seperti Lembaga Perlindungan Konsumen Swadaya Masyarakat (LPKSM), POLRI dan Penyidik Pegawai Negeri Sipil (PPNS), Badan Penyelesaian Sengketa Konsumen (BPSK) dan para Hakim agar senantiasa menegakan hukum perlindungan konsumen sebaik-baiknya dengan melaksanakan tugas dan fungsinya masing-masing sebagaimana ditentukan dalam ketentuan Peraturan PerundangUndangan 


\section{DAFTAR PUSTAKA}

- Buku-Buku:

Ade Maman Suherman, 2005, Aspek Hukum Dalam Ekonomi Global, Cet.ke 2 (Edisi Revisi), Ghalia Indonesia, Bogor

M. Ali Mansyur, 2012, Peran Hukum Dalam Menjawab Perkembangan Ekonomi, Makalah Disampaikan Pada Kuliah Peranan Hukum Dalam PembangunanEkonomi, Bagian Hukum Perdata Fakultas Hukum Universitas Islam Sultan Agung, Semarang;

Muladi, 2010, Aspek Hukum Globalisasi, penerbit: UNDIP, Semarang;

Sri adiningsih, 1998, Pemberdaulatan Ekonomi Rakyat Untuk Meningkatkan Kesejahteraan Masyarakat, Kertas Karya pada seminar FE Unissula, Semarang

Talcot Parsons, 1951, The Social System, The Free Press, New York

- Peraturan perundang-undangan:

Undang-Undang Nomor 8 Tahun 1999 Tentang perlindungan Konsumen.

- Website :

www.ekbis.sindonews.com

www.Zulkifli19.wordpress.com

http://www.bsn.go.id/ 